\title{
Proposal That the Species Vibrio anguillarum Bergman 1909, Vibrio piscium David 1927, and Vibrio ichthyodermis (Wells and ZoBell) Shewan, Hobbs, and Hodgkiss 1960 Be Combined as a Single Species, Vibrio anguillarum
}

\author{
MARGARET S. HENDRIE, W. HODGKISS, and J. M. SHEWAN
}

Torry Research Station, Aberdeen, AB9 8DG, Scotland

\begin{abstract}
The characteristics of seven strains identified as Vibrio anguillarum, Vibrio piscium var. japonicus, or Vibrio ichthyodermis are compared with those in the original descriptions of these taxa. A proposal is made to combine all strains as a single species, Vibrio anguillarum Bergman.
\end{abstract}

The implication of vibrios as the causal organisms of diseased conditions in fish was first recognized by Bergman (4), who isolated from eels an organism which resembled the cholera vibrio and which he called Vibrio anguillarum. David (5) isolated an organism from carp and named it Vibrio piscium, using the argument that, as it was from freshwater fish, it was a different species from $V$. anguillarum. Subsequently, Wells and ZoBell (14) isolated a polarly flagellated rod from diseased marine fish, proposing the name Achromobacter ichthyodermis, a correct taxonomic assignment at that time. No reference was made by Wells and ZoBell to the work of either Bergman or David. ZoBell and Upham (15) proposed that $A$. ichthyodermis should be included in the genus Pseudomonas.

In 1950, Hodgkiss and Shewan (6) isolated an organism from a diseased plaice which, on comparison with the information in the 6th edition of Bergey's Manual of Determinative Bacteriology, they concluded was Pseudomonas ichthyodermis. Later Shewan, Hobbs, and Hodgkiss (11) suggested that the organism belonged in the genus Vibrio.

Other fish-pathogenic organisms belonging to the genus Vibrio have been isolated from cod by Bagge and Bagge (1), who concluded that their organism was a strain of $V$. anguillarum; from rainbow trout by Hoshina ( 7 ), who named his organism $V$. piscium var. japonicus, as it was not identical to David's original description of $V$. piscium; and from finnock by Smith (12), who showed that her organisms were similar to Bagge and Bagge's strain of $V$. anguillarum. Furthermore, Smith (12) suggested that the Hoshina (7) strains were nearer to $V$. anguillarum than to $V$. piscium.

During a comprehensive study of vibrios and related organisms $(2,3)$ and the routine checking of cultures held in the National Collection of Marine Bacteria, it has become clear that the three species $V$. anguillarum, $V$. piscium var. japonicus, and $V$. ichthyodermis are phenotypically similar. No original isolates from Bergman (4), David (5), or Wells and ZoBell (14) are available, but cultures from Hodgkiss and Shewan (6), Bagge and Bagge (1), Hoshina (7), and Smith (12) have all been compared. The results are given in Table 1 , along with information on $V$. anguillarum (4), $V$. piscium (5), and $A$. ichthyodermis (14).

Bergman and David's results are not identical with those obtained for the strains held in the NCMB, but as only a very limited amount of information can be gleaned from these papers and because the methods used for certain tests, e.g., carbohydrate breakdown, are not comparable to ours, their data are of limited value.

To our knowledge, no original strains exist for $V$. anguillarum Bergman 1909, $V$. piscium David 1927, or A. ichthyodermis Wells and 
ZoBell 1934. Until a large number of strains can be examined and a suitable neotype selected, we suggest that the following strains are useful representatives of $V$. anguillarum: NCMB $6=$ ATCC $19264=$ Bagge and Bagge strain; NCMB $407=$ strain PL 1 of Hodgkiss and Shewan; NCMB 571, a strain from Hoshina; and NCMB $828=$ ATCC $14181=$ strain 4063 from Smith.

We agree with the recommendation of Ross et al. (9) that $V$. anguillarum should be included in the 8 th edition of Bergey's Manual.

Vibrio anguillarum Bergman 1909. [Subjective synonyms: Vibrio piscium David 1927; Achromobacter ichthyodermis Wells and ZoBell 1934; Pseudomonas ichthyodermis (Wells and ZoBell) ZoBell and Upham 1944; Vibrio piscium var. japonicus Hoshina 1957]; Vibrio ichthyodermis (Wells and ZoBell) Shewan, Hobbs, and Hodgkiss 1960.]

anguillarum L. noun anguilla eel; gen. pl. anguillarum of eels.

Short rods, axis straight or curved, sides parallel, ends rounded, occurring singly and in pairs, pleomorphic, 0.5 to 0.7 by 1.0 to $2.0 \mu \mathrm{m}$. Motile by means of polar flagella, usually monotrichous (Fig. 1), but lophotrichous forms may occur. Gram-negative.

Nutrient agar colonies: Off-white to buff, translucent or opaque, circular, convex, entire margin, smooth, shiny, 1.0 to $2.0 \mathrm{~mm}$ in diameter. Colony variation can occur within individual strains.

Horse blood agar: Abundant greyish growth, usually beta-hemolytic.

Nutrient broth: Good growth with off-white pellicle and uniform turbidity. Thickness of pellicle and density of turbidity varies from strain to strain.

Growth at temperatures from 5 to $30 \mathrm{C}$, generally no growth at $37 \mathrm{C}$ (Bergman records growth at $38 \mathrm{C}$ ), optimum usually 20 to $25 \mathrm{C}$. Growth in nutrient broth without added $\mathrm{NaC} 1$ and with up to $5 \% \mathrm{NaCl}$. Growth at $p \mathrm{H} 6$ to 9; no growth at $p \mathrm{H} 5$.

Insensitive to penicillin, but sensitive to streptomycin, chloramphenicol, aureomycin, terramycin, tetracycline, erythromycin, neomycin, novobiocin, polymyxin $B$, and the vibriostatic compound 0/129 (2:4-diamino-6:7diisopropyl pteridine).

Indole produced.

Acetylmethylcarbinol usually produced; $2: 3$ butanediol usually positive (Bullock's method).

Methyl red test negative.

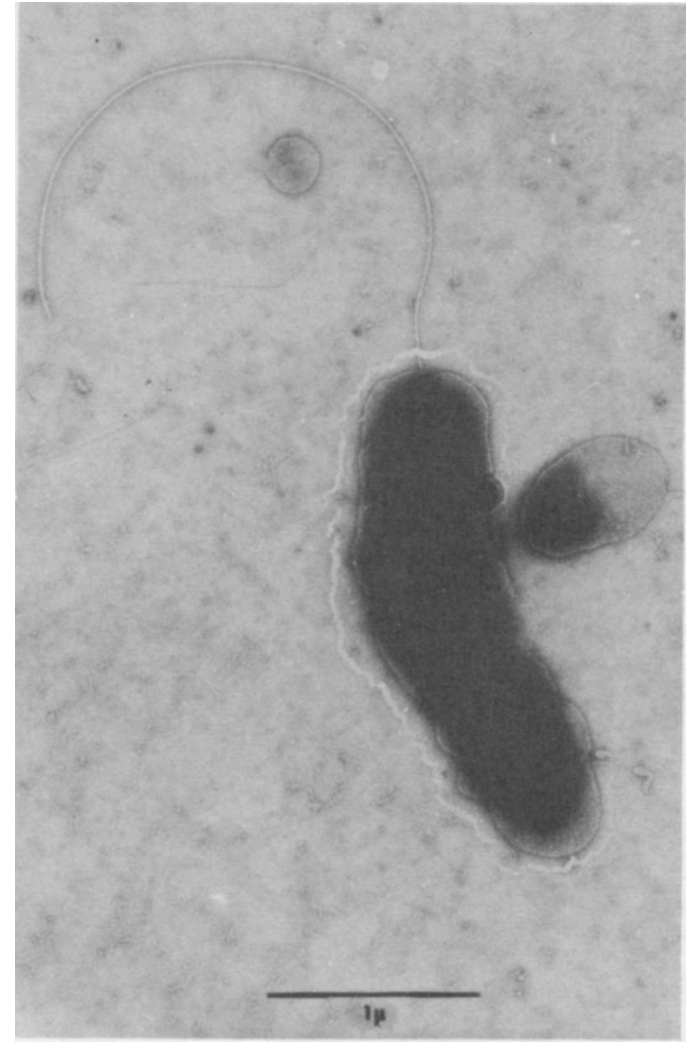

Fig. 1. Vibrio anguillarum strain NCMB 6. Twenty-four hours on sea water agar at $20 \mathrm{C}$. Negatively stained with phosphotungstic acid. $\times 20,000$.

Ammonia produced from peptone but not from urea.

Nitrites produced from nitrates.

Trimethylamine oxide reduced to trimethylamine.

Citrate not utilized as sole carbon source.

Gelatin, starch, and casein hydrolyzed. Carbohydrate metabolism fermentative.

Acid but no gas produced from glucose, fructose, galactose, mannose, sucrose, maltose, trehalose, mannitol, sorbitol, dextrin, glycogen, and starch. Acid may or may not be produced in cellobiose, rhamnose, glycerol, inositol, and salicin. No acid from lactose, arabinose, xylose, ribose, sorbose, raffinose, or dulcitol.

Alkaline reaction in Møller's arginine medium, but no lysine or ornithine decarboxylases are produced.

Deoxyribonucleic acid base ratio: $44.5 \pm 1.5$ moles per cent guanine plus cytosine.

Habitat: Water, marine and fresh. Cause of ulcerous lesions in marine and freshwater fish. 
TABLE 1. Comparison of Vibrio anguillarum, Vibrio piscium var. japonicus, and Vibrio ichthyodermis with originally published information on V. anguillarum Bergman 1909, V. piscium David 1927, and Achromobacter ichthyodermis Wells and ZoBell 1934

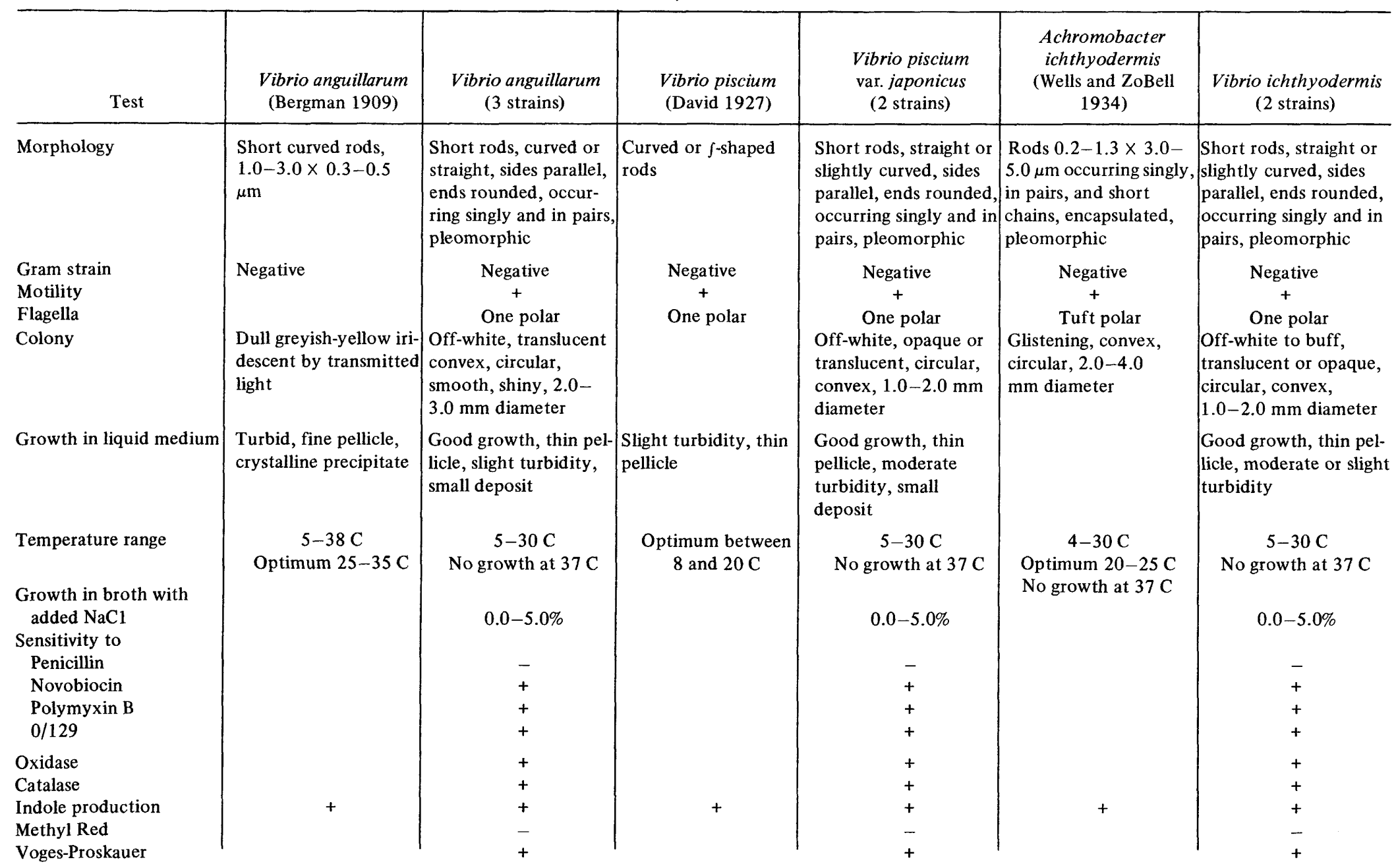


Ammonia from peptone Nitrate reduction

$\mathrm{H}_{2} \mathrm{~S}$ production

Trimethylamine oxide reduction

Citrate utilization

Hemolysis

Starch hydrolysis

Gelatin hydrolysis

Casein hydrolysis

Milk

Glucose metabolism

"Sugar" media

Glucose

Fructose

Galactose

Mannose

a Lactose

Sucrose

Maltose

Arabinose

Xylose

Dulcitol

Glycerol

Inositol

Mannitol

Sorbitol

Salicin

Dextrin

Starch

Glycogen

Møller's (1955)

Arginine reaction

Lysine reaction

Ornithine reaction

Moles \% GC

\begin{tabular}{c|c}
+ To nitrite & + \\
- & + To nitrite \\
& + \\
& - \\
& + \\
Coagulated acid & + \\
peptonized & +
\end{tabular}

Fermentative

Not coagulated by fresh isolates

Acid

Acid

Acid

Acid

Acid

Acid

Variable

-

Acid (variable)

Acid

Acid

-

Acid

Acid

Acid

Alkaline

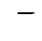

44.5 (Sebald and Véron; 1 strain)

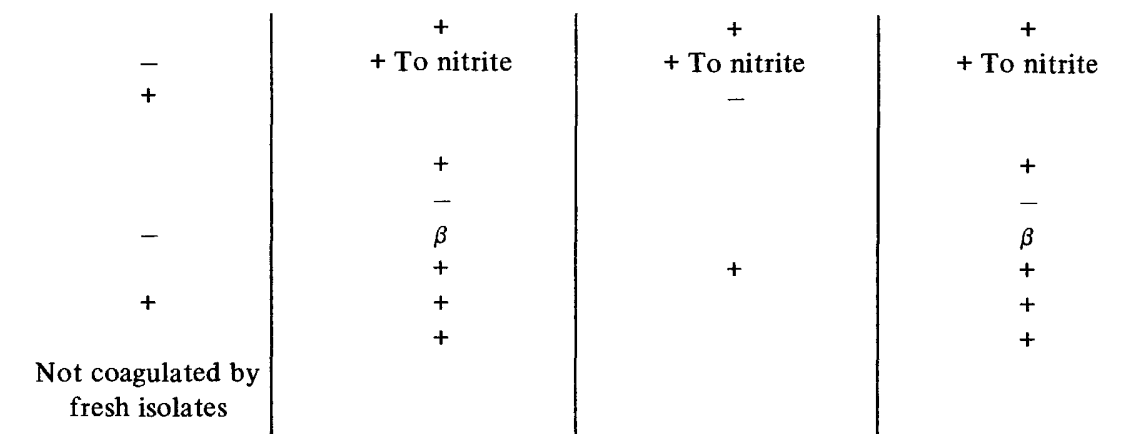

Fermentative

Acid

Fermentative

Acid

Acid

Acid

Acid

Acid

Acid

$-$

$-$

Acid

Acid

Acid

Acid

Acid

Acid

Alkaline

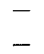

44.7 (Véron and Sebald; 1 strain) 


\section{LITERATURE CITED}

1. Bagge, J., and O. Bagge. 1956. Vibrio anguillarum som årsag til ulcussygdom hos torsk (Gadus callarius, Linné) (Vibrio anguillarum as a cause of an ulcerous disease in cod (Gadus callarius L.)]. Nord. Vet. Med. 8:481-492.

2. Bain, N., and J. M. Shewan. 1968. The identification of Aeromonas, Vibrio and related organisms, p. 79-84. In B. M. Gibbs and D. A. Shapton (ed.), Identification methods for microbiologists, part B. Academic Press Inc., New York.

3. Bain, N., M. E. Taylor, and J. M. Shewan. 1965. Some preliminary data on a study of the Vibrio and allied genera. Spisy Prirodoved. Fak. Univ. J. E. Purkyne Brne 7: Serie K 298-299.

4. Bergman, A. M. 1909. Die rote Beulenkrankheit des Aals. Ber. Kgl. Bayer. Biol. Verssta. 2:10-54.

5. David, H. 1927. Ueber eine durch choleraähnliche Vibrionen hervorgerufene Fischseuche. Zentralbl. Bakteriol. Parasitenk. Abt. I, Orig. 102:46-60.

6. Hodgkiss, W., and J. M. Shewan. 1950. Pseudomonas infection in a plaice. J. Pathol. Bacteriol. 62:655-657.

7. Hoshina, T. 1957. Further observations on the causative bacteria of the epidemic disease like furunculosis of rainbow-trout. J. Tokyo Univ. Fish. 43:59-66.

8. Møller, V. 1955. Simplified tests for some amino acid decarboxylases and for the arginine dihydrolase system. Acta Pathol. Microbiol. Scand. 36:18.

9. Ross, A. J., J. E. Martin, and V. Bressler. 1968. Vibrio anguillarum from an epizootic in Rainbow trout (Salmo gairdneri) in the USA. Bull. Off. Int. Epizool. 69:1139-1148.

10. Sebald, M., and M. Véron. 1963. Teneur en bases le l'ADN et classification des vibriones. Ann. Inst. Pasteur Paris 105:897-910.

11. Shewan, J. M., G. Hobbs, and W. Hodgkiss. 1960. A determinative scheme for the identification of certain genera of gram-negative bacteria, with special reference to the Pseudomonadaceae. J. Appl. Bacteriol. 23:379-390.

12. Smith, I. W. 1961. A disease of finnock due to Vibrio anguillarum. J. Gen. Microbiol. 24:247-252.

13. Véron, M., and M. Sebald. 1964. Sur la teneur en bases de l'ADN et la position taxonomique de Vibrio ichthyodermis, Shewan, Hobbs et Hodgkiss, 1960. Ann. Inst. Pasteur Paris 108:422-423.

14. Wells, N. A., and C. E. ZoBell. 1934. Achromobacter ichthyodermis, n. sp., the etiological agent of an infectious dermatitis of certain marine fishes. Proc. Nat. Acad. Sci. U.S.A. 20:123-126.

15. ZoBell, C. E., and H. C. Upham. 1944. A list of marine bacteria including descriptions of sixty new species. Bull. Scripps Inst. Oceanogr. 5:239-292. 